UDC 541.13

\author{
S. Minu Xavier Sebastini, P. Daniel Nixon, C. Joseph Kennady
}

\title{
ELECTRODEPOSITION OF NICKEL HYDROXIDE FOR SUPERCAPACITOR APPLICATIONS USING SURFACTANT-CONTAINING ELECTROLYTE
}

\author{
Karunya Institute of Technology and Sciences, Coimbatore, India
}

\begin{abstract}
Nickel hydroxide is a promising material for supercapacitor application due to its relatively low cost, well-defined electrochemical redox nature and easy to prepare with different structural morphologies. In the present study, nickel hydroxide was cathodically deposited on a stainless steel surface from an electrolyte containing $\mathrm{Ni}\left(\mathrm{NO}_{3}\right)_{2}$ as a result of local increase in $\mathrm{pH}$ at the cathode. A nonionic surfactant (Pluronic $\mathrm{P}$ 123, $\left.\mathrm{HO}\left(\mathrm{CH}_{2} \mathrm{CH}_{2} \mathrm{O}\right)_{20}\left(\mathrm{CH}_{2} \mathrm{CH}\left(\mathrm{CH}_{3}\right) \mathrm{O}\right)_{70}\left(\mathrm{CH}_{2} \mathrm{CH}_{2} \mathrm{O}\right)_{20} \mathrm{H}\right)$ was added to the solution in order to get enhanced nanocrystalline nickel hydroxide film. The film was characterized using scanning electron microscopy, energy dispersive X-ray analysis, X-ray diffraction method and Fourier transform infrared spectroscopy to investigate its surface and morphological characteristics. The grain size of the as prepared nickel hydroxide was about $11 \mathrm{~nm}$ and this was achieved because of the presence of nonionic surfactant, which influences the microstructure of the deposit. Cyclic voltammetry was used to study the reduction and oxidation processes in the electrodeposited nickel hydroxide electrode, characterize the specific capacitance and evaluate the suitability of the synthesized films for supercapacitor application. The charge-discharge dependences were recorded to study the capacitive property of the material. The results showed that the prepared nickel hydroxide electrodes have specific capacitance of about $494 \mathrm{~F} / \mathrm{g}$.
\end{abstract}

Keywords: super capacitor, oxide electrode, surfactant, electrodeposition, surface characterization, cyclic voltammetry, charge-discharge curve.

DOI: $10.32434 / 0321-4095-2020-131-4-128-133$

\section{Introduction}

An interest in development of supercapacitors has increased recently because of the high demand for energy production and storage resulting from rapid population growth and high-energy consumption in the industrial sector [1]. Various electrode materials can be used in supercapacitors [2,3]. Metal oxidebased supercapacitors as storage devices are gaining momentum in recent years due to their fast power energy delivery, extended life cycle and high power and reasonably high energy density. Among different oxides, $\mathrm{RuO}_{2}$ and amorphous hydrous ruthenium oxide are the most capable material for supercapacitors because of their elevated specific capacitance, excellent reversibility and long cyclelife $[4,5]$. However, this material's high cost and potential to harm the environment have limited its commercial application in supercapacitors. Several alternative electrode materials have been studied, including carbonaceous materials, conducting polymers, metal hydroxides and metal oxides [6-9]. Base metal oxides, such as $\mathrm{MnO}_{2}, \mathrm{NiO}, \mathrm{Fe}_{3} \mathrm{O}_{4}$ and $\mathrm{Mn}-\mathrm{Ni}$ oxide, have been proposed as promising electrode materials because of their environmental compatibility, low cost, abundant availability, environmental compatibility and wide potential windows [10-12].

Different electrode materials that have low cost, comparable capacitive behavior as compared with ruthenium oxide were studied. $\mathrm{NiO}$ found to be a potential alternative to $\mathrm{RuO}_{2}$ as electrode material. $\mathrm{NiO}$ films exhibit high specific capacitance value [13] and many authors studied this material in varying aspects. Some examples are as follows: nanocrystalline $\mathrm{NiO}[14]$, nanoporous electrodeposited nickel oxide films [15], nickel oxide/ hydroxide nanoplatelets [16], and nickel oxide films on different substrates [17].

In the present study, $\mathrm{Ni}(\mathrm{OH})_{2}$ films were electrodeposited on stainless steel at room 
temperature from an electrolyte containing a nonionic surfactant in order to get more refined nanostructure. The deposited nickel hydroxide electrodes were annealed at $300^{\circ} \mathrm{C}$. The surface and morphological characterization of the prepared nickel oxide films was performed by using X-ray diffraction method, energy dispersive $\mathrm{X}$-ray analysis and scanning electron microscopy. The deposited nickel hydroxide electrodes were also subjected to FT-IR study to ascertain the bonding and stretching between nickel and hydroxide. Cyclic voltammetry and galvanostatic charge-discharge studies were carried out using the structurally and morphologically optimized nickel oxide electrode to study the redox behavior and calculate the specific capacitance value.

\section{Materials and methods}

Stainless steel (grade 304) samples with the dimensions of $1.0 \times 3.0 \times 0.1 \mathrm{~cm}$ were used as a substrate for electrodepositing nickel hydroxide. The substrate was fine polished with emery paper and washed with distilled water. To get a uniform etching of the surface, the substrate was immersed in a solution containing $0.5 \mathrm{ml} / \mathrm{L}$ of concentrated sulfuric and hydrochloric acid each. Time of dipping was 2030 minutes. $\mathrm{Ni}(\mathrm{OH})_{2}$ was electrodeposited from a solution containing $0.1 \mathrm{M}$ of nickel nitrate. $0.1 \mathrm{~g} / \mathrm{L}$ of Pluronic P123 surfactant was added to this solution. Nickel nitrate was a source for $\mathrm{Ni}(\mathrm{OH})_{2}$ and the surfactant acted as a structure directing agent which does not participate in electrochemical reactions.

The surfactant was a symmetric triblock copolymer comprising polyethylene oxide (PEO) and polypropylene oxide (PPO) in an alternating linear fashion, $\mathrm{PEO}-\mathrm{PPO}-\mathrm{PEO}$. It's chemical formula is $\mathrm{HO}\left(\mathrm{CH}_{2} \mathrm{CH}_{2} \mathrm{O}\right)_{20}\left(\mathrm{CH}_{2} \mathrm{CH}\left(\mathrm{CH}_{3}\right) \mathrm{O}\right)_{70}\left(\mathrm{CH}_{2} \mathrm{CH}_{2} \mathrm{O}\right)_{20} \mathrm{H}$. This surfactant was chosen due to its high molecular weight and alternate arrangement of PEO and PPO. The $\mathrm{pH}$ of the solution was 5.1. All experiments were carried out at $30^{\circ} \mathrm{C}$.

Nickel hydroxide film was electrodeposited using an Electrochemical Workstation-CHI770d. The electrochemical cell consisted of three electrodes, i.e. pre-treated stainless steel acted as a working electrode, platinum wire was a counter electrode and $\mathrm{Ag} / \mathrm{AgCl}$ electrode served as a reference electrode. The electrolysis was carried out under the potentiostatic conditions by applying electrode potentials of $-0.7,-0.9$ and $-1.1 \mathrm{~V}$. The duration of electrodeposition was fixed as 60 minutes. After electrodeposition, the working electrode was taken out, rinsed with distilled water and annealed at $300^{\circ} \mathrm{C}$ for 60 minutes.

The prepared nickel oxide electrodes were subjected to structural and morphological study using X-ray diffraction method (XRD) and scanning electron microscopy (SEM). Elements present in the electrode were analyzed by means of energy dispersive $X$-ray analysis (EDAX). Cyclic voltammetry $(\mathrm{CV})$ experiments were carried out with the prepared nickel oxide electrode using CHI 770d instrument. For cyclic voltammetric experiments, the electrode surface was masked and an area of $0.196 \mathrm{~cm}^{2}$ was exposed to the electrolyte. The constant current charge-discharge behavior of the nickel oxide electrode was investigated galvanostatically at a current of $5 \mathrm{~mA}$.

\section{Results and discussion}

\section{Electrodeposition}

The deposition of well adherent and uniform dark green colored nickel oxide was performed by applying a constant potential of $-0.9 \mathrm{~V}$ vs. $\mathrm{Ag} / \mathrm{AgCl}$ for a deposition time of $60 \mathrm{~min}$. It is demonstrated that the electrodeposition process of the $\mathrm{Ni}(\mathrm{OH})_{2}$ films could include an electrochemical reaction followed by a precipitation reaction expressed as follows:

$$
\begin{gathered}
\mathrm{NO}_{3}{ }^{-}+7 \mathrm{H}_{2} \mathrm{O}+8 \mathrm{e}^{-} \rightarrow \mathrm{NH}_{4}{ }^{+}+10 \mathrm{OH}^{-}, \\
\mathrm{Ni}^{2+}+2 \mathrm{OH}^{-} \rightarrow \mathrm{Ni}(\mathrm{OH})_{2} .
\end{gathered}
$$

When electric current passes through the electrolyte containing $\mathrm{Ni}\left(\mathrm{NO}_{3}\right)_{2}$, nitrate ions are reduced on the cathodic surface to produce hydroxide ions. The generation of $\mathrm{OH}^{-}$ions at the cathode raises the local $\mathrm{pH}$, resulting in the precipitation of $\mathrm{Ni}(\mathrm{OH})_{2}$ at the electrode surface. The deposited electrode was annealed at $300^{\circ} \mathrm{C}$ for 2 hours.

\section{Structural and morphological studies}

Figure 1 represents the results of X-ray diffraction analysis which was used to determine the crystalline phase, orientation and grain size of the prepared materials. The experimental data were compared with the crystal structures available in PCPDF WIN crystal structure database. The different peaks with various intensities were marked and the d-values were calculated from these peaks. The grain size was calculated using Scherrer formula:

$$
\text { Grain size }\left(\mathrm{X}_{\mathrm{s}}\right)=\mathrm{k} \lambda / \beta \cos \theta,
$$

where $\mathrm{X}_{\mathrm{s}}$ is the size of crystalline, $\lambda$ is $\mathrm{X}$-ray wavelength, $\beta$ is full width at half maximum of the diffraction peak, $\theta$ is diffraction angle and $\mathrm{k}$ is Scherer constant.

The grain size of the prepared nickel hydroxide was about $11 \mathrm{~nm}$ and this was achieved because of the application of a nonionic surfactant, which 
enhanced the orientation of atom building in the deposit.

The morphological nature of the deposited $\mathrm{Ni}(\mathrm{OH})_{2}$ was examined using scanning electron microscopy. SEM micrograph (Fig. 2) reveals that the deposited $\mathrm{Ni}(\mathrm{OH})_{2}$ is uniform and shows minor cracks in its surface. Porous space observed in between may enhance the redox behavior of the oxide. In this structure, fine-grained nanostructure is also visible which is due to the presence of surfactant in the electrolyte.

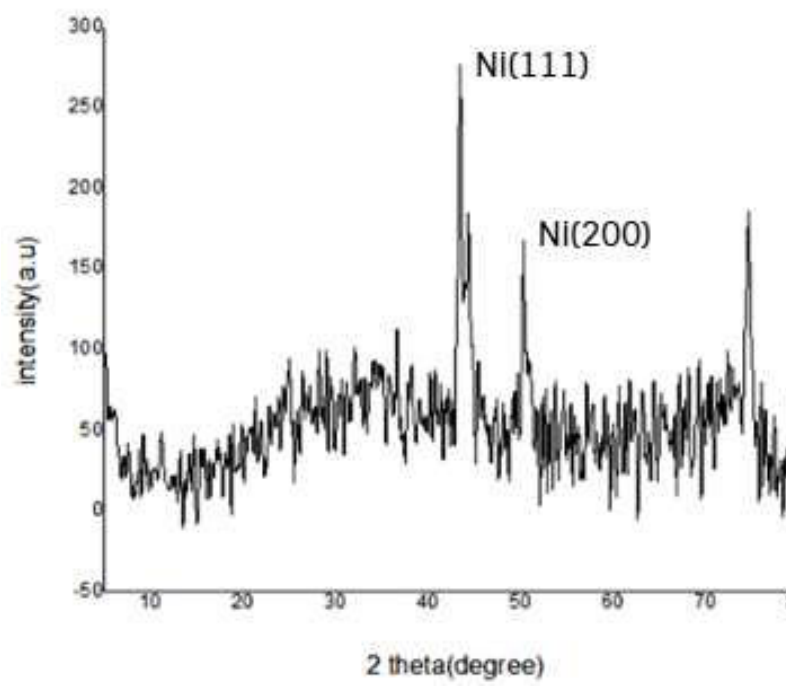

Fig. 1. XRD pattern of the electrodeposited $\mathrm{Ni}(\mathrm{OH})_{2}$ film

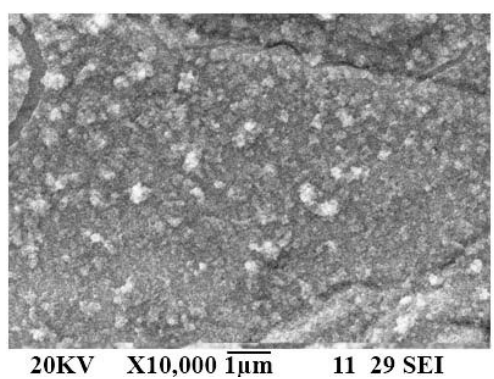

Fig. 2. SEM image of the electrodeposited $\mathrm{Ni}(\mathrm{OH})_{2}$

The result of EDAX study is presented in Fig. 3. EDAX confirms the presence of nickel. Also, iron and chromium were detected; they were in the substrate, stainless steel, which was used for the electrodeposition. This result indicates that there are no other impurities in the obtained film.

\section{FTIR study}

Figure 4 shows the FTIR spectrum of the prepared $\mathrm{Ni}(\mathrm{OH})_{2}$ which can reveal the presence of some organic and inorganic functional groups in $\mathrm{Ni}(\mathrm{OH})_{2}$. The peak at $619 \mathrm{~cm}^{-1}$ arises from the in-

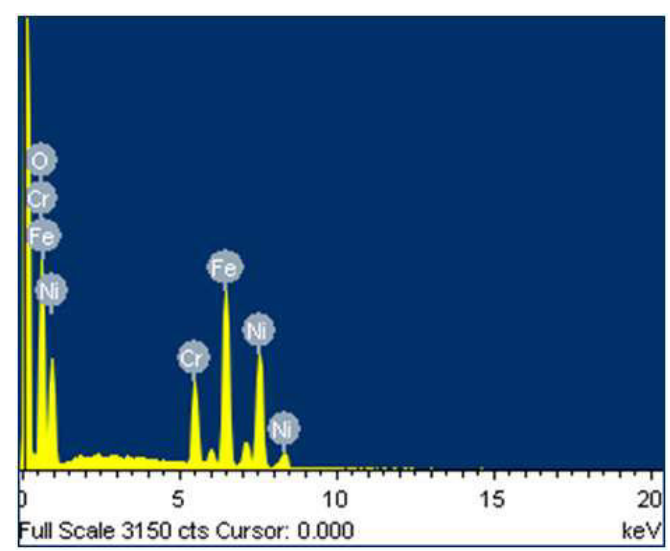

Fig. 3. EDAX graph of the electrodeposited $\mathrm{Ni}(\mathrm{OH})_{2}$

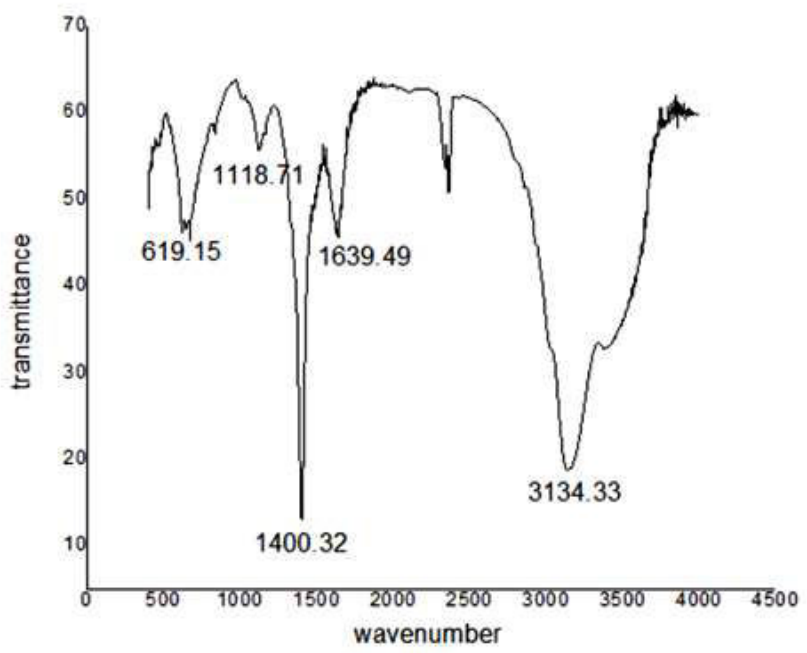

Fig. 4. FTIR spectrum of electrodeposited $\mathrm{Ni}(\mathrm{OH})_{2}$

plane $\mathrm{Ni}-\mathrm{OH}$ bending vibration of the $\mathrm{Ni}(\mathrm{OH})_{2}$ lattice. The broad peak at $1400 \mathrm{~cm}^{-1}$ was attributed to $\mathrm{O}-\mathrm{H}$ bending of lattice $\mathrm{OH}$. The absorption band at $3134 \mathrm{~cm}^{-1}$ is associated with hydrogen-bonded $\mathrm{OH}$ stretching.

Cyclic voltammetry study

Cyclic voltammetric experiments were carried out in $2 \mathrm{M} \mathrm{KOH}$ electrolyte. The $\mathrm{CV}$ curve for $\mathrm{Ni}(\mathrm{OH})_{2}$ deposited on stainless steel sheet at different scan rate with a potential window $-0.5 \mathrm{~V}$ to $0.5 \mathrm{~V}$ are presented in Fig. 5. There is a peak in the reverse sweep in all the cyclic voltammograms; it represents the reduction of $\mathrm{Ni}^{4+}$ to $\mathrm{Ni}^{2+}$. This $\mathrm{Ni}^{2+}$ ions in the forward sweep is oxidized forming $\mathrm{Ni}^{4+}$ which was not noticed by a prominent peak, since the potentials of the hydrogen evolution reaction and the nickel oxidation overlap each other.

Charge-discharge study

The constant current charge-discharge behavior of the nickel oxide electrode was investigated 

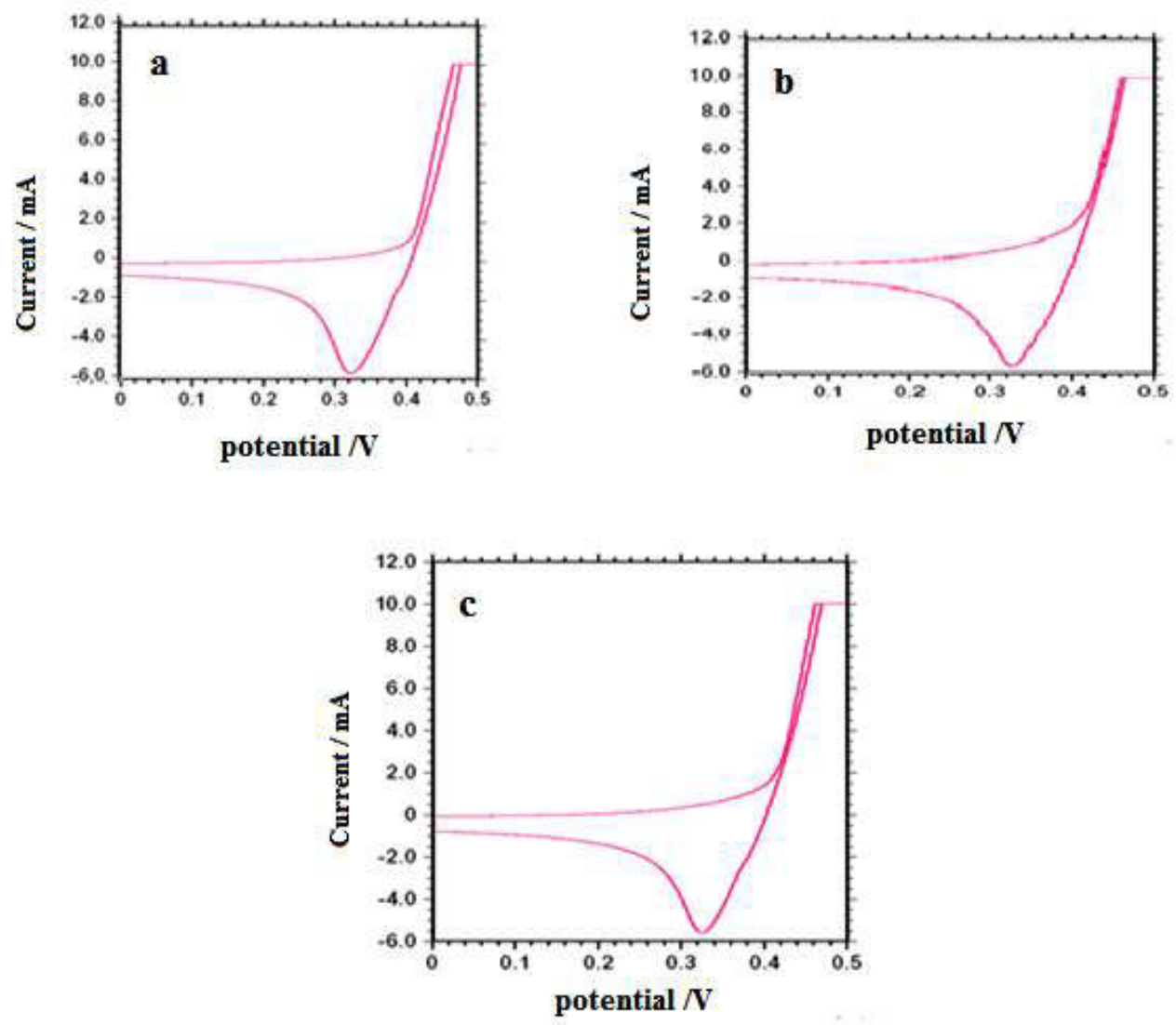

Fig. 5. Cyclic voltammograms of nickel hydroxide in $2.0 \mathrm{M} \mathrm{KOH}$ at a scan rate of (a) 20, (b) 50 and (c) $100 \mathrm{mV} / \mathrm{s}$

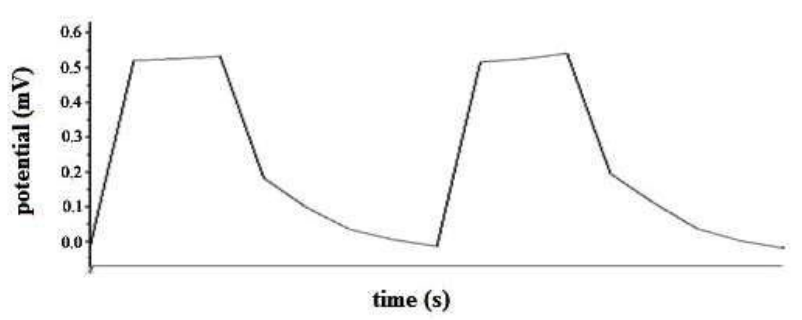

Fig. 6. Charge-discharge curve of the electrodeposited $\mathrm{Ni}(\mathrm{OH})_{2}$ electrode in $2.0 \mathrm{M} \mathrm{KOH}$

galvanostatically at a current of $5 \mathrm{~mA}$. The resultant plot is illustrated in Fig. 6. It is seen from the plot that electrodeposited $\mathrm{Ni}(\mathrm{OH})_{2}$ can hold the charge for longer duration and thereby it can be used as an electrode material for supercapacitors. The result suggests that the $\mathrm{Ni}(\mathrm{OH})_{2}$ electrode has a good rate capability, which is very important for the electrode materials of a supercapacitor to provide high power density. Based on the charge-discharge plot obtained, specific capacitance was calculated and found to be $494 \mathrm{~F} / \mathrm{g}$.

\section{Conclusions}

The electrodeposition of $\mathrm{Ni}(\mathrm{OH})_{2}$ electrode from an electrolyte containing nickel nitrate and a nonionic surfactant yields a uniform smooth nanosized electrode material. The SEM micrograph reveals that the deposited $\mathrm{Ni}(\mathrm{OH})_{2}$ is uniform in its surface morphology and exhibit minor cracks on the surface. Porous space observed in between enhances the redox behavior of the oxide. Fine-grained nanostructure is also visible. XRD result reveals that the grain size of the electrodeposited nickel hydroxide is about $11 \mathrm{~nm}$. This was achieved because of the nonionic surfactant, which enhances the orientation of atom building in the deposit. EDAX confirms the presence of nickel and also iron and chromium, which are in the substrate, stainless steel, used for the electrodeposition. In FTIR spectrum, the peak at $619 \mathrm{~cm}^{-1}$ arises from the in-plane $\mathrm{Ni}-\mathrm{OH}$ bending vibration of the a- $\mathrm{Ni}(\mathrm{OH})_{2}$ lattice.

There is a peak in the reverse sweep of the cyclic voltammogram, it represents the reduction of $\mathrm{Ni}^{4+}$ to $\mathrm{Ni}^{2+}$. This $\mathrm{Ni}^{2+}$ in the forward sweep oxidizes forming $\mathrm{Ni}^{4+}$ that is not noticed by a prominent peak, which may be due to overlapping the potentials of hydrogen evolution nickel (II) oxidation. The charge-discharge plot shows that the electrodeposited $\mathrm{Ni}(\mathrm{OH})_{2}$ film can hold the charge for longer duration and thereby it can be used as an electrode material 
for supercapacitors. Based on the charge-discharge plot obtained, specific capacitance was calculated and found to be $494 \mathrm{~F} / \mathrm{g}$. The smaller particle size with effective electroactive surface area of the electrode is responsible for the improved charge transfer performance of the oxide electrode. This is possible because of the nanosized structure of the nickel oxide electrode, which was achieved by the presence of the surfactant. The nonionic surfactant enhances the orientation of atom building in the deposit.

\section{REFERENCES}

1. Suhasini. Effect of deposition method and the surfactant on high capacitance of electrochemically deposited $\mathrm{MnO}_{2}$ on stainless steel substrate // J. Electroanal. Chem. - 2013. - Vol.690. - P.13-18.

2. Wang G., Zhang L., Zhang J. A review of electrode materials for electrochemical supercapacitors // Chem. Soc. Rev. - 2012. - Vol.41. - P.797-828.

3. Iro Z.S., Subramani C., Dash S.S. A brief review on electrode materials for supercapacitors // Int. J. Electrochem. Sci. - 2016. - Vol.11. - P.10628-10643.

4. Synthesis, chemical polymerization and electrochemical properties of low band gap conducting polymers for use in supercapacitors / Soudan P., Lucas P., Ho H.A., Jobin D., Breau L., Belanger D. // J. Mater. Chem. - 2001. - Vol.11. - P.773-782.

5. Solid state thin-film supercapacitor with ruthenium oxide and solid electrolyte thin films / Yoon Y.S., Cho W.I., Lim J.H., Choi D.J. // J. Power Sources. - 2001. - Vol.101. - P.126-129.

6. Preparation and electrochemical performances of a- $\mathrm{MnO}_{2}$ nanorod for supercapacitor / Li Y., Xie H., Wang J., Chen L. // Mater. Lett. - 2011. - Vol.65. - P.403-405.

7. Babakhani B., Ivey D.G. Anodic deposition of manganese oxide electrodes with rod-like structures for application as electrochemical capacitors // J. Power Sources. - 2010. - Vol.195. - P.2110-2117.

8. Progress of electrochemical capacitor electrode materials: a review / Zhang Y., Feng H., Wu X., Wang L., Zhang A., Xia T., Dong H., Li X., Zhang L. // Int. J. Hydrogen Energy. - 2009. Vol.34. - P.4889-4899.

9. Lokhande C.D., Dubal D.P., Joo O.S. Metal oxide thin film based supercapacitors // Curr. Appl. Phys. - 2011. - Vol.11. - P.255-270.

10. Post-synthetic functionalization of mesoporous carbon electrodes with copper oxide nanoparticles for supercapacitor application / Prasad K.P.S., Dhawale D.S., Joseph S., Anand C., Wahab M.A., Mano A., Sathish C.I., Balasubramanian V.V., Sivakumar T., Vinu A. // Microporous Mesoporous Mater. 2013. - Vol.172. - P.77-86.

11. Wang H., Gao Q., Hu J. Asymmetric capacitor based on superior porous $\mathrm{Ni}-\mathrm{Zn}-\mathrm{Co}$ oxide/hydroxide and carbon electrodes // J. Power Sources. - 2010. - Vol.195. - P.30173024.

12. Daniel Nixon P., Joseph Kennady C. Electrodeposition of manganese-nickel oxide films for supercapacitor applications // Voprosy Khimii i Khimicheskoi Tekhnologii. - 2019. No. 6. - P.144-148.

13. Liu K.C., Anderson M.A. Porous nickel oxide/nickel films for electrochemical capacitors // J. Electrochem. Soc. 1996. - Vol.143. - P.124.

14. Zhang F., Zhou Y., Li H. Nanocrystalline $\mathrm{NiO}$ as an electrode material for electrochemical capacitor // Mater. Chem. Phys. - 2004. - Vol.83. - P.260-264.

15. Electrodeposition of nanoporous nickel oxide film for electrochemical capacitors / Wu M.S., Huang Y.A., Yang C.H., Jow J.J. // Int. J. Hydrogen Energy. - 2007. - Vol.32. - P.41534159.

16. Wu M.S., Hsieh H.H. Nickel oxide/hydroxide nanoplatelets synthesized by chemical precipitation for electrochemical capacitors // Electrochim. Acta. - 2008. - Vol.53. - P.3427-3435.

17. Comparative studies of nickel oxide films on different substrates for electrochemical supercapacitors / Wu M., Gao J., Zhang S., Chen A. // J. Power Sources. - 2006. - Vol.159. P.365-369.

Received 20.04.2020

\section{ЕЛЕКТРООСАДЖЕННЯ НІКЕЛЬ ГІДРОКСИДУ ДЛЯ ВИКОРИСТАННЯ У СУПЕРКОНДЕНСАТОРАХ 3 ВИКОРИСТАННЯМ ЕЛЕКТРОЛІТУ, ЩО МІСТИТЬ ПОВЕРХНЕВО-АКТИВНУ РЕЧОВИНУ}

\section{С. Міну Ксав'єр Себастіні, П. Даніель Ніксон, К. Джозеф Кеннеді}

Нікель(II) гідроксид є перспективним матеріалом для використання в суперконденсаторах через його відносно низьку вартість, однозначну електрохімічну редокс-поведінку і простоту синтезу зразків з різноманітною структурною морфологією. В даній роботі нікель(II) гідроксид був катодно осаджений на поверхні нержавіючої сталі з електроліту, що містив $\mathrm{Ni}\left(\mathrm{NO}_{3}\right)_{2}$, у результаті локального підвищення рН біля катода. at the cathode. Неіоногенна поверхнево-активна речовина (Pluronic P 123, $\mathrm{HO}\left(\mathrm{CH}_{2} \mathrm{CH}_{2} \mathrm{O}\right)_{20}\left(\mathrm{CH}_{2} \mathrm{CH}\left(\mathrm{CH}_{3}\right) \mathrm{O}\right)_{70}\left(\mathrm{CH}_{2} \mathrm{CH}_{2} \mathrm{O}\right)_{20} \mathrm{H}$ ) додавалася до розчину з метою отримати покращений нанокристалічних шар нікель(II) гідроксиду. Отримані шари були характеризовані методами сканівної електронної мікроскопії, енергорозсіювального рентгенівського аналізу, рентгеноструктурного методу та інфрачервоної спектроскопії з Фур'є-перетворенням для вивчення поверхневих та морфологічних характеристик. Розмір кристалітів виготовленого нікель(II) гідроксиду дорівнював приблизно $11 \mathrm{нм}$, що досягнуто за рахунок наявності неіоногенної поверхнево-активної речовини, що впливає на мікроструктуру осаду. Циклічна вольтамперометрія була використана для дослідження процесів окислення і відновлення в електроосадженому гідкроксидно-нікелевому електроді, а також для визначення питомої ємності і оцінювання придатності синтезованих шарів для використання в суперконденсаторах. Зарядно-розрядні залежсності були використані для вивчення ємнісних властивостей одержаного матеріалу. Резуль- 
тати дослідження показали, що виготовлені гідкроксидно-нікелеві електроди мають питому ємність близько 494 Ф/2.

Ключові слова: суперконденсатор; оксидний електрод; поверхнево-активна речовина; електроосадження; характеристики поверхні; циклічна вольтамперометрія; зарядно-розрядна крива.

\section{ELECTRODEPOSITION OF NICKEL HYDROXIDE FOR SUPERCAPACITOR APPLICATIONS USING SURFACTANT-CONTAINING ELECTROLYTE}

S. Minu Xavier Sebastini, P. Daniel Nixon, C. Joseph Kennady Karunya Institute of Technology and Sciences, Coimbatore, India

\section{* e-mail: kennady@karunya.edu}

Nickel hydroxide is a promising material for supercapacitor application due to its relatively low cost, well-defined electrochemical redox nature and easy to prepare with different structural morphologies. In the present study, nickel hydroxide was cathodically deposited on a stainless steel surface from an electrolyte containing $\mathrm{Ni}\left(\mathrm{NO}_{3}\right)_{2}$ as a result of local increase in $\mathrm{pH}$ at the cathode. A nonionic surfactant (Pluronic P 123, $\left.\mathrm{HO}\left(\mathrm{CH}_{2} \mathrm{CH}_{2} \mathrm{O}\right)_{20}\left(\mathrm{CH}_{2} \mathrm{CH}\left(\mathrm{CH}_{3}\right) \mathrm{O}\right)_{70}\left(\mathrm{CH}_{2} \mathrm{CH}_{2} \mathrm{O}\right)_{20} \mathrm{H}\right)$ was added to the solution in order to get enhanced nanocrystalline nickel hydroxide film. The film was characterized using scanning electron microscopy, energy dispersive $X$-ray analysis, $X$-ray diffraction method and Fourier transform infrared spectroscopy to investigate its surface and morphological characteristics. The grain size of the as prepared nickel hydroxide was about $11 \mathrm{~nm}$ and this was achieved because of the presence of nonionic surfactant, which influences the microstructure of the deposit. Cyclic voltammetry was used to study the reduction and oxidation processes in the electrodeposited nickel hydroxide electrode, characterize the specific capacitance and evaluate the suitability of the synthesized films for supercapacitor application. The charge-discharge dependences were recorded to study the capacitive property of the material. The results showed that the prepared nickel hydroxide electrodes have specific capacitance of about $494 \mathrm{~F} / \mathrm{g}$.

Keywords: super capacitor; oxide electrode; surfactant; electrodeposition; surface characterization; cyclic voltammetry; charge-discharge curve.

\section{REFERENCES}

1. Suhasini. Effect of deposition method and the surfactant on high capacitance of electrochemically deposited $\mathrm{MnO}_{2}$ on stainless steel substrate. Journal of Electroanalytical Chemistry, 2013, vol. 690 , pp. 13-18.

2. Wang G., Zhang L., Zhang J. A review of electrode materials for electrochemical supercapacitors. Chemical Society Reviews, 2012, vol. 41, pp. 797-828.

3. Iro Z.S., Subramani C., Dash S.S. A brief review on electrode materials for supercapacitors. International Journal of Electrochemical Science, 2016, vol. 11, pp. 10628-10643.

4. Soudan P., Lucas P., Ho H.A., Jobin D., Breau L., Belanger D. Synthesis, chemical polymerization and electrochemical properties of low band gap conducting polymers for use in supercapacitors. Journal of Materials Chemistry, 2001, vol. 11, pp. 773-782.
5. Yoon Y.S., Cho W.I., Lim J.H., Choi D.J. Solid state thin-film supercapacitor with ruthenium oxide and solid electrolyte thin films. Journal of Power Sources, 2001, vol. 101, pp. 126-129.

6. Li Y., Xie H., Wang J., Chen L. Preparation and electrochemical performances of $\alpha-\mathrm{MnO}_{2}$ nanorod for supercapacitor. Materials Letters, 2011, vol. 65, pp. 403-405.

7. Babakhani B., Ivey D.G. Anodic deposition of manganese oxide electrodes with rod-like structures for application as electrochemical capacitors. Journal of Power Sources, 2010, vol. 195 , pp. $2110-2117$.

8. Zhang Y., Feng H., Wu X., Wang L., Zhang A., Xia T., Dong H., Li X., Zhang L. Progress of electrochemical capacitor electrode materials: a review. International Journal of Hydrogen Energy, 2009, vol. 34, pp. 4889-4899.

9. Lokhande C.D., Dubal D.P., Joo O.S. Metal oxide thin film based supercapacitors. Current Applied Physics, 2011, vol. 11, pp. 255-270.

10. Prasad K.P.S., Dhawale D.S., Joseph S., Anand C., Wahab M.A., Mano A., Sathish C.I., Balasubramanian V.V., Sivakumar T., Vinu A. Post-synthetic functionalization of mesoporous carbon electrodes with copper oxide nanoparticles for supercapacitor application. Microporous and Mesoporous Materials, 2013, vol. 172, pp. 77-86.

11. Wang H., Gao Q., Hu J. Asymmetric capacitor based on superior porous $\mathrm{Ni}-\mathrm{Zn}-\mathrm{Co}$ oxide/hydroxide and carbon electrodes. Journal of Power Sources, 2010, vol. 195, pp. 3017-3024.

12. Daniel Nixon P., Joseph Kennady C. Electrodeposition of manganese-nickel oxide films for supercapacitor applications. Voprosy Khimii i Khimicheskoi Tekhnologii, 2019, no. 6, pp. 144-148.

13. Liu K.C., Anderson M.A. Porous nickel oxide/nickel films for electrochemical capacitors. Journal of the Electrochemical Society, 1996, vol. 143, pp. 124.

14. Zhang F., Zhou Y., Li H. Nanocrystalline $\mathrm{NiO}$ as an electrode material for electrochemical capacitor. Materials Chemistry and Physics, 2004, vol. 83, pp. 260-264.

15. Wu M.S., Huang Y.A., Yang C.H., Jow J.J. Electrodeposition of nanoporous nickel oxide film for electrochemical capacitors. International Journal of Hydrogen Energy, 2007, vol. 32, pp. 4153-4159.

16. Wu M.S., Hsieh H.H. Nickel oxide/hydroxide nanoplatelets synthesized by chemical precipitation for electrochemical capacitors. Electrochimica Acta, 2008, vol. 53, pp. 3427-3435.

17. Wu M., Gao J., Zhang S., Chen A. Comparative studies of nickel oxide films on different substrates for electrochemical supercapacitors. Journal of Power Sources, 2006, vol. 159, pp. 365-369. 